\title{
A model for accurate histopathologic assessment refines treatment options
}

\author{
Paul H. Sugarbaker ${ }^{1}$, Kurt Van der Speeten ${ }^{2}$ \\ ${ }^{1}$ MedStar Washington Hospital Center, Washington, DC, USA; ${ }^{2}$ Department of Surgery, Hospital Oost-Limburg, Genk, Belgium \\ Correspondence to: Paul H. Sugarbaker, MD. MedStar Washington Hospital Center, Washington, DC, USA. Email: Paul.Sugarbaker@outlook.com; \\ Kurt Van der Speeten. Department of Surgery, Hospital Oost-Limburg, Genk, Belgium. Email: Kurt.Vanderspeeten@zol.be. \\ Comment on: Carr NJ. New insights in the pathology of peritoneal surface malignancy. J Gastrointest Oncol 2021;12:S216-29.
}

Submitted Dec 16, 2020. Accepted for publication Mar 16, 2021.

doi: 10.21037/jgo-2020-20

View this article at: http://dx.doi.org/10.21037/jgo-2020-20

The Editors are grateful to Norman Carr for his presentation of the pathology of primary appendiceal mucinous neoplasm and its PM (1). The clear distinction of the different histopathologic types and their clear association with outcome has made a tremendous difference in the management of peritoneal metastases from appendiceal malignancy. Ultimately, a standardized pathological reporting terminology is critical in correct analysis of clinical outcome data. What a great service to the clinician! The pathologist would deserve a similar distinction if histopathologic types were available for peritoneal mesothelioma, for gastric cancer, and colon cancer. Definitely, ovarian malignancy would profit from a histomorphologic assessment of aggressive versus nonaggressive diseases. This work on appendiceal malignancy points the way towards innovative histopathologic studies with other peritoneal surface malignancies.

\section{Acknowledgments}

Funding: None.

\section{Footnote}

Provenance and Peer Review: This article was commissioned by the editorial office, Fournal of Gastrointestinal Oncology for the focused issue "Intraperitoneal Chemotherapy for Peritoneal Metastases: HIPEC, EPIC, NIPEC, PIPAC and More". The article did not undergo external peer review.

Conflicts of Interest: Both authors have completed the ICMJE uniform disclosure form (available at http:// dx.doi.org/10.21037/jgo-2020-20). The focused issue was sponsored by the Peritoneal Surface Oncology Group International (PSOGI). Drs. PHS and KVDS served as the unpaid Guest Editors of the focused issue. The authors have no other conflicts of interest to declare.

Ethical Statement: The authors are accountable for all aspects of the work in ensuring that questions related to the accuracy or integrity of any part of the work are appropriately investigated and resolved.

Open Access Statement: This is an Open Access article distributed in accordance with the Creative Commons Attribution-NonCommercial-NoDerivs 4.0 International License (CC BY-NC-ND 4.0), which permits the noncommercial replication and distribution of the article with the strict proviso that no changes or edits are made and the original work is properly cited (including links to both the formal publication through the relevant DOI and the license). See: https://creativecommons.org/licenses/by-nc-nd/4.0/.

\section{References}

1. Carr NJ. New insights in the pathology of peritoneal surface malignancy. J Gastrointest Oncol 2021;12:S216-29.

Cite this article as: Sugarbaker PH, Van der Speeten K. A model for accurate histopathologic assessment refines treatment options. J Gastrointest Oncol 2021;12(Suppl 1):S230. doi: 10.21037/jgo-2020-20 